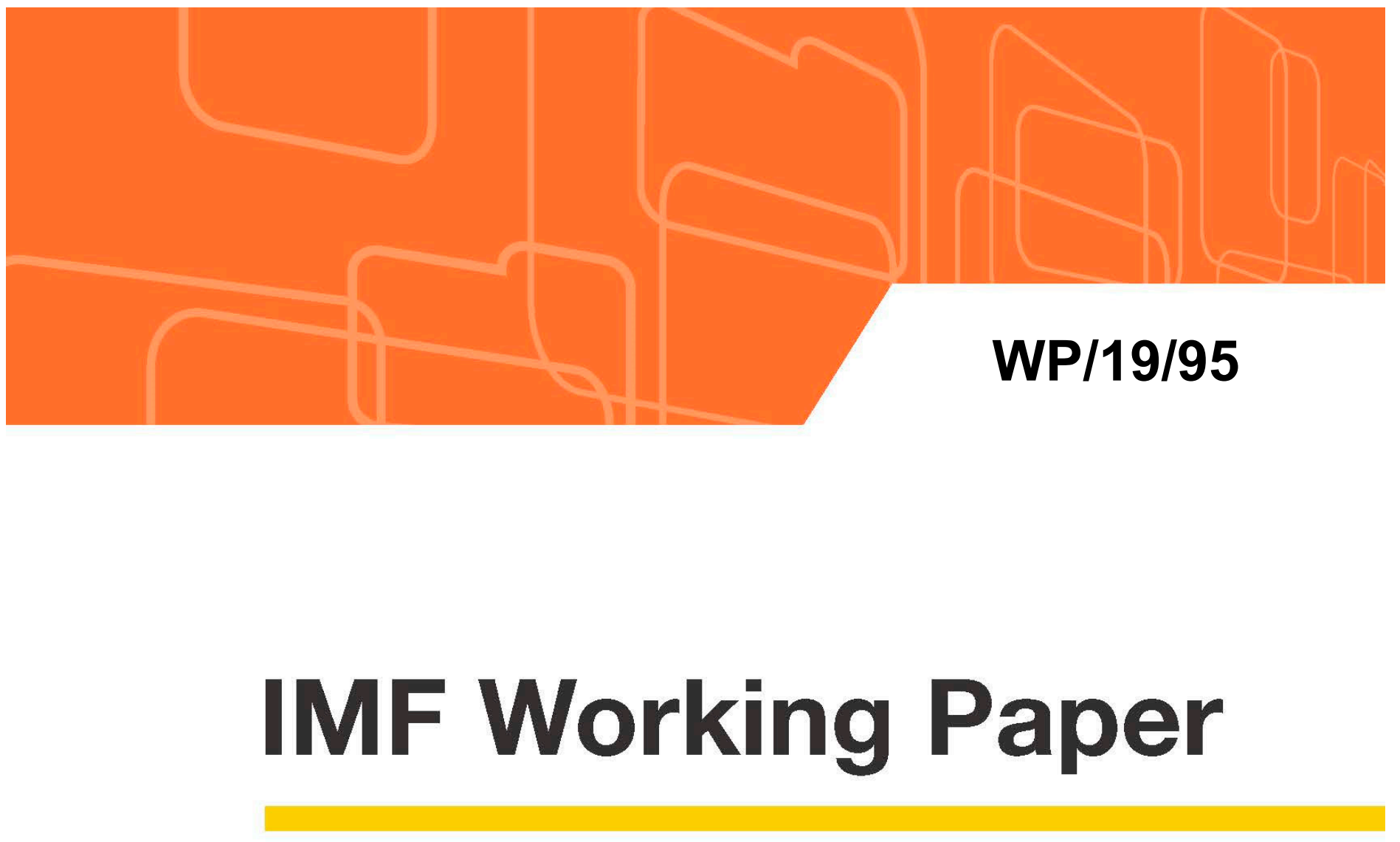

\title{
Globalization, Market Power, and the Natural Interest Rate
}

by Jean-Marc Natal and Nicolas Stoffels

IMF Working Papers describe research in progress by the author(s) and are published to elicit comments and to encourage debate. The views expressed in IMF Working Papers are those of the author(s) and do not necessarily represent the views of the IMF, its Executive Board, or IMF management. 


\title{
IMF Working Paper
}

European Department

\section{Globalization, Market Power, and the Natural Interest Rate \\ Prepared by Jean-Marc Natal and Nicolas Stoffels ${ }^{1}$}

Authorized for distribution by Julie Kozack

May 2019

IMF Working Papers describe research in progress by the author(s) and are published to elicit comments and to encourage debate. The views expressed in IMF Working Papers are those of the author(s) and do not necessarily represent the views of the IMF, its Executive Board, or IMF management.

\begin{abstract}
We argue that strong globalization forces have been an important determinant of global real interest rates over the last five decades, as they have been key drivers of changes in the natural real interest rate-i.e. the interest rate consistent with output at its potential and constant inflation. An important implication of our analysis is that increased competition in goods and labor market since the 1970s can help explain both the large increase in real interest rates up to the mid-1980s and - as globalization forces mature and may even go into reverse, leading to incrementally rising market power-its subsequent and protracted decline accompanied by lower inflation. The analysis has important implications for monetary policy and the optimal pace of normalization.
\end{abstract}

JEL Classification Numbers: D43, D58, E17, E43, E44, E52, F62

Keywords: low interest rate puzzle; globalization; natural interest rate; real interest rates; markups

Author's E-Mail Address: jnatal@imf.org; nicolas.stoffels@snb.ch

\footnotetext{
${ }^{1}$ Swiss National Bank. The views expressed in this paper are those of the author(s) and do not necessarily represent those of the Swiss National Bank
} 
TABLE OF CONTENTS

ABSTRACT

I. INTRODUCTION 3

II. GLOBALIZATION AND THE NATURAL INTEREST RATE 5

A. A Simple Neo-classical Model of the World Economy 7

B. Deriving the World Natural Real Interest Rate 8

III. EFFECTS OF GLOBALIZATION ON THE NATURAL INTEREST RATE

A. Non-linear Implications of Global Integration 9

B. How Large is the "Globalization Premium"? 11

IV. EMPIRICAL EVIDENCE 11

A. The Specification 11

B. Data Regression Results 13

V. INSIGHTS FROM A LARGE MODEL OF THE GLOBAL ECONOMY 14

A. GIMF in a Nutshell____ 15

B. Calibration ___ 15

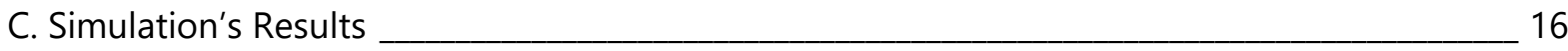

VI. SUMMARY AND CONCLUSION___ 16

\section{TABLES}

1. OLS Estimates of Fundamental Drivers of Real Interest Rates, 1985-2016 14

\section{APPENDIX}

Figures 17 


\section{INTRODUCTION}

Over the last five decades, there has been substantial variation in global real interest rates, both short-term and long-term. According to IMF data (Figure 1), globally aggregated real rates have been low and flat in the 1960s, declining in the first half of the 1970s before rising strongly until the mid-1980s' peak. Since then, real rates have been trending down.

This downward trend has persisted throughout various monetary and fiscal policy cycles, periods of financial euphoria and stress. Interestingly, the decline in long-term real interest rates has extended to the mid-2000s, a period characterized by a sharp acceleration in global growth and a decline in inflation (see Figures 2 and 3). Importantly, over the whole period, real rates have tightly co-moved across most regions, suggesting common structural drivers. ${ }^{2}$

Given that real interest rates are the key asset prices governing the intertemporal allocation of spending, the analysis of their fundamental determinants has attracted considerable attention from scholars and policymakers alike. Most authors have focused their analysis on the downward trend since the mid-1980s (for recent reviews see e.g. Fischer 2017; Obstfeld and Tesar July 2015; and IMF's WEO April 2014, chapter 3).

The rapidly expanding literature on what has come to be known as the "low interest rate puzzle" can be broken down into two related but different strands. The first strand revolves around mostly circumstantial—presumably persistent but not permanent—causes, which have affected global savings and investment. As popularized by Bernanke (2005), the saving glut theory states that, before the financial crisis, large excess savings from emerging markets in Asia and oil exporter countries had materialized, widening current accounts worldwide and pushing down interest rates. During and in the aftermath of the crisis, the deleveraging trends in advanced economies depressed domestic spending, notably investment, leading to narrowing external imbalances while keeping interest rates down. The natural real interest rate, i.e. the interest rate consistent with output at its potential and constant inflation, may even have declined so much that the global economy could now be trapped in a vicious circle: the zero lower bound prevents market real interest rates from finding their equilibrium value, leading in turn to insufficient demand and chronic unemployment, a phenomenon dubbed 'secular stagnation' (Summers 2014; Eggertson and Merhotra 2014). Other studies have brought financial factors to the forefront, in particular the chronic shortage of safe and liquid assets. Global supply of safe assets plummeted in the wake of the financial crisis while their demand, mostly from emerging economies, remained robust, pushing down the natural safe rate (Caballero et al 2007; Del Negro et al 2017; Gourinchas and Rey 2017; Marx et al 2017).

The second strand focuses on more lasting, secular developments as the main reason behind the decline in equilibrium real interest rates. First, the global slowdown in productivity and labor force expansion may have discouraged capital formation (Laubach and Williams 2003; Holston et al 2016). Second, demographic developments not directly related to labor force growth such as aging, may have stimulated savings. Cohorts with a high propensity to save have tended to expand faster than the rest of the population leading to a rise in high-saving groups.

Furthermore, as life expectancy is rising faster than the average retirement age, households have to save more to provide for longer retirement years (Gagnon et al 2016; Carvalho et al 2016).

\footnotetext{
${ }^{2}$ See also Yi and Zhang 2016, Figure 1.
} 
Third, rising income and wealth inequality in a number of countries may have amplified the phenomenon, because rich households tend to save a larger part of their income (Dynan et al 2004; Cynamon and Fazzari 2014; Piketty and Saez 2014). Fourth, technologically driven declines in prices of investment goods (Sajedi and Thwaites 2016) may have limited the global demand for investment financing.

Our paper complements the second strand of literature by arguing that the secular process of global goods and labor market integration-also known as globalization-has played a significant, though largely neglected, role in driving the underlying, low frequency, dynamics of real interest rates around the globe over the last fifty years. We claim that greater competition stemming from the integration of goods and labor markets has contributed to push markups down and the global natural real interest rate up-i.e. the interest rate consistent with output at its potential and constant inflation - from the mid-1970s to early 1980 s. $^{3}$ In the decades that followed, as the globalization process matured and the pace of further competition gains slowed, natural interest rates climbed down again and reverted gradually to their 1970s levels. ${ }^{4}$ In the event of sustained increases in firms' market power that may have characterized the last decade or so, as argued in a more recent literature, the pace of decline in the natural interest rate would be accentuated. ${ }^{5}$

The basic mechanism linking natural real interest rates to changes in the degree of global competition-or market power-is very similar to the one involving productivity growth. If market power is expected to rise, lower competition on the labor and goods markets will shrink the economy's future production capacity-like would lower productivity-spurring consumption and investment spending to slow, and thus pushing interest rates down. Conversely, if more competition is expected, real interest rates will edge up as firms expand investment and households front-load consumption in the perspective of higher income. But there is here an important difference with expected productivity growth. The increase in competition is by nature a bounded process: perfect competition is the limit. Therefore, as globalization progresses (and competition approaches its limit), it does so at a declining pace, driving interest rates back down.

The paper makes three contributions. First, in Section 2, we show that through its effect on competition and markups, the process of globalization introduces an important non-linearity in the Euler equation of the standard neo-classical macro-model that governs the pricing of safe assets. Initially, real interest rates go up as the globalization process kicks in but, because the efficiency gains stemming from the integration of goods and labor markets are bounded (by the perfect competition limit), short- and long-term natural interest rates have to trend down again. This description conforms nicely with the observed pattern of real interest rates since the $1980 \mathrm{~s}$. Furthermore, because the integration of goods and labor market is a global phenomenon, this approach offers a natural explanation for the strong co-movement across countries. The direct implication of this analysis is that the protracted decline in the natural real rate of interest since

\footnotetext{
${ }^{3}$ Cyclical conditions also played an important role during this period. In particular, the U.S. Fed led by Paul Volker adopted a restrictive stance to address elevated price pressures, raising the real interest rates well beyond their long-run equilibrium levels (Hamilton et al 2015, p.16). In the years that followed, inflation ebbed significantly allowing the Fed to normalize its monetary stance.

${ }^{4}$ Empirical estimates by Lubik and Matthes (2015, p.4, Figure 3) of the real natural interest rate fit this pattern well, with relatively low levels in the 1970s, a rise in the 1980s, and a substantial decline during the 2000 s.

${ }^{5}$ For an illustration of the negative effect of increasing markups on the natural interest rate see IMF (2019, p. 66, Figure 2.9). We discuss the recent literature on market power in section 2.
} 
the mid-1980s helps understand the coincidence of a downward trend in real long-term bond yields with lower inflation. A rise in market power (from a retrenchment from globalization or from other reasons) would further amplify the decline in the natural real interest rate. Second, we argue in Section 3 that, based on a reasonable calibration of the model, protracted markup changes generate significant variations in the natural real interest rate. In Section 4, we show that there is a close relationship between import penetration, a proxy for goods and labor market integration, and real interest rates, both short- and long-term, over the last 30 years. This finding holds up when we control for productivity growth. Finally, we show that these results are not artifacts of the simple model presented in Sections 2 and 3. In Section 5 we confirm the importance of globalization in driving real interest rates by repeating the theoretical experiment within a multi-sector, multi-country model of the global economy that features real, nominal and financial frictions. We show that the increase and subsequent decline in real interest rates is consistent with the simulations preformed with the simple model, and output and inflation patterns that correspond to stylized facts.

\section{Globalization and the Natural Interest Rate}

This section examines the analytical relationship between globalization and the natural real interest rate. Technological advances (in communication and transportation), geopolitical shifts (such as the end of the cold war) as well as the integration of large emerging markets (in particular China) into the global trade system and the creation of vast international supply chains have led to a momentous increase in trade flows. Bars in Figure 4 plot the evolution in the (inverted) ratio of world imports of goods and services to world GDP since 1960. The ratio of world imports to world GDP remained relatively stable around 12 percent until the early 70 s, when it embarked on an almost four-decade long upward trend. Since 2008 it has leveled-off near 30 percent.

A body of literature has shown that increased global integration forces domestic firms and workers to relinquish rents. ${ }^{6}$ While competitiveness pressures erode firms' pricing power and price markups, the threat of offshoring erodes workers' bargaining power (Rodrick, 1997) and wage markups. And the two phenomena might even be linked. Globalization, by pressuring firms' markups, may have decreased the incentives for workers to appropriate the now smaller rents. ${ }^{7}$ All in all, by introducing more competition in both goods and labor markets, globalization has arguably led to a decline in private rents and pushed the global economy closer to its efficient level. Figure 4 shows the tight co-movement between (inverted) global import

\footnotetext{
${ }^{6}$ Theoretical models have stressed the negative impact of economic integration on price markups. For instance, when increased foreign competition makes more product varieties available, it reduces the market share of domestic firms and raises the price elasticity of demand (Feenstra and Weinstein, 2017; Chen et al., 2009 or Krugman, 1979). For empirical estimates see Feenstra and Weinstein (2017), Edmond et al (2015), De Blas and Russ (2015), Badinger (2007), Tybout (2001), Harrison (1994) and Levinsohn (1993).

${ }^{7}$ Blanchard and Giavazzi (2001) show how increased competition in goods and labor markets leads to a redistribution of rents between firms and workers. Abraham et al. (2009) and Dobbelaere (2005) find that workers' bargaining power and firms' markups in the manufacturing sector in Belgium are positively associated. Furthermore, Abraham et al. (2009) find that import penetration has a negative and significant effect on both the price markup and on the bargaining power of unions. Boulhol et al (2011) documents a significant decline in workers' bargaining power and firms' markups during 1994-2003 in UK's manufacturing sector.
} 
penetration (a proxy for globalization) and a macro-economic estimate of total markups, defined as the sum of price and wage markups and derived from the simple model presented in the next sub-section. ${ }^{8}$

To investigate the link between globalization and the natural real interest rate, we rely on the frictionless version of the standard New-Keynesian model (the simple neo-classical model), featuring imperfect competition in product and labor markets. Because the natural real interest rate is the rate consistent with output at potential and constant inflation, it is determined by the flexible price solution to the model (Gali, 2008). The basic economic mechanism is described by the Euler equation for consumption, which characterizes the interplay between variations in income (current and prospective) and the households' desire to smooth consumption. In a nutshell, variations in goods' and labor market's markups-which act like changes in distortionary taxation - affect output and labor income by altering the degree of efficiency in the economy. A decrease in markups brings the economy closer to its efficient production level and generates additional income. As agents want to smooth consumption overtime, they will not be willing to alter their consumption patterns to match variations in output unless the relative price of future consumption - the natural interest rate-changes correspondingly. Intuitively, declining markups act very much like increases in productivity: both induce a rise in expected future income and lead to a higher natural rate of interest, which incentivizes forward-looking households to postpone consumption. ${ }^{9}$

In what follows we call 'globalization premium' the component of the natural rate of interest associated with expectations of increased competition in the future. We argue that, for reasonable parameterization, the 'globalization premium' can be quite sizable and may thus have contributed to explain the rise in real interest rates as global integration started in earnest in the mid-70s. However, and this is important to explain the last 30 years' decline in interest rates, markups are bounded from below (the perfect competition limit implies zero markups), so that the pace of globalization has to eventually abate. It means that, as globalization matures and markups approach their lower bound, the globalization premium gradually disappears and the real interest rate tends to revert to its original (lower) level of equilibrium.

Before turning to the model, it is important to note that the view that firms' market power has declined since the 1980 s is fiercely debated. A recent literature argues that firms' market power has in fact increased markedly since the 1980s. According to Loecker and Eeckout $(2017,2018)$ "in 1980, average U.S. markups start to rise from 18 percent above marginal costs to 60 percent now. ${ }^{10}$ By contrast, using a similar approach but another estimation method, Traina (2018) shows flat or even decreasing markups in recent decades in the US. A similar conclusion is reached by a Deutsche Bundesbank (2017) study on several European economies.

\footnotetext{
${ }^{8}$ Based on the mathematical derivation from the simple model in Section 2.1 and as stated in footnote 13, the total markup is calculated as the ratio between global productivity and real consumption per capita. The data on productivity was obtained from the OECD Economic Outlook Dataset (2017), while the data on consumption was extracted from the Penn World Table 9.0. For a visualization of the total markup see Figure 4.

${ }^{9}$ Adding capital formation to the model would add a supplementary source of upward pressure on interest rates as firms raise investment demand in the face of increased productive efficiency.

10 Diez et al., (2018) reach similar conclusions for advanced economies. IMF (2019) documents a moderate rise in price markups in several developed economies since 2000.
} 
However, our central result does not hinge on the outcome of this debate. First, our analysis does not only consider price markups, but also wage markups, reflecting workers' bargaining power. It is therefore conceivable that total markups have been declining even if price markups have been increasing. Second, and most importantly, the claim that markups may have risen in the last decade or so does not invalidate our argument. If markups do not only slow down, while approaching the perfect-competition limit, but in fact rise, the drop in the natural interest rate would be accentuated.

\section{A. A Simple Neo-Classical Model of the World Economy}

We outline a very stylized model of the world economy where imperfect competition is assumed on both goods and labor markets (see e.g. Gali, 2008). ${ }^{11}$ Firms produce a continuum of goods indexed by $i \in[0,1]$ using linear production technology. ${ }^{12}$ Each representative firm produces an amount of differentiated variety $i$ according to:

$$
Y_{\tau}(i)=A_{\tau} N_{\tau}(i)
$$

where $A_{\tau}$ denotes an exogenous technology shifter common to all firms, and $N_{\tau}(i)$ is an index of imperfectly substitutable labor inputs used for the production of good $i$ at time $\tau$.

Households, indexed by $j \in[0,1]$, are forward looking, and maximize their lifetime intertemporal expected utility $\mathcal{U}$ at time $t$ :

$$
u_{t}=E_{t}\left[\sum_{\tau=t}^{\infty} \beta^{\tau-t} U_{\tau}(j)\right]
$$

where $U_{\tau}(j)=U_{\tau}\left[C_{\tau}(j), N_{\tau}(j)\right]$ is household $j$ separable period utility function, and $C_{\tau}(j) \equiv$ $\left(\int_{0}^{1} C_{\tau}(i, j)^{1-\frac{1}{\epsilon_{p}}} d i\right)^{\frac{\epsilon_{p}}{\epsilon_{p}-1}}$ is its consumption basket. Households offer a continuum of labor types $N_{\tau}(j)$ and set their wage $W_{\tau}(j)$. The labor input used by firm $i$ is defined by $N_{\tau}(i) \equiv$ $\left(\int_{0}^{1} N_{\tau}(i, j)^{1-\frac{1}{\epsilon_{w}}} d j\right)^{\frac{\epsilon w}{\epsilon_{w^{-1}}}}$.

Household choices are bounded by the flow budget constraint:

$$
\begin{aligned}
P_{\tau} C_{\tau}(j) & +B_{\tau}(j) \leq\left(1+R_{\tau-1}\right) B_{\tau-1}(j) \\
& +W_{\tau}(j) N_{\tau}(j)+\Pi_{\tau}(j),
\end{aligned}
$$

where $P_{\tau} C_{\tau}(j)=\int_{0}^{1} P_{\tau}(i) C_{\tau}(i, j) d i$ is the household total level of expenditure, and by the usual solvency constraint $\lim _{\tau \rightarrow \infty} E_{t}\left\{B_{\tau}\right\} \geq 0$. The nominal yield $R_{\tau-1}$ on the one-period riskless bond $B_{\tau-1}$ is known at time $\tau-1$ and received at the beginning of period $\tau$. Profits from production $\Pi_{\tau}(j)$ are handed back to households in form of dividends.

\footnotetext{
11 Since the focus is on the global interest rate, we abstract from international wealth transfers and trade frictions (see Natal and Stoffels 2007 for an open economy version of the model) and assume full capital mobility.

12 Introducing capital in a Cobb-Douglas production function would not alter any of the paper's findings.
} 
Households maximize utility subject to technical and budget constraints and firms maximize profits. Given our focus on the natural real interest rate, we assume that prices and wages are perfectly flexible. Dropping all indices (symmetric equilibrium), and solving for households' optimal saving, consumption and labor supply (leisure) decisions by maximizing (2) under the budget constraint (3), leads to the following optimality conditions:

$$
\begin{gathered}
\left(1+R_{\tau}\right) \beta E_{\tau} \Lambda_{\tau+1}=\Lambda_{\tau}, \\
\frac{\partial U_{\tau}}{\partial C_{\tau}}-\Lambda_{\tau} P_{\tau}=0
\end{gathered}
$$

with $\Lambda_{\tau}$ the time varying Lagrange multiplier on the budget constraint and:

$$
\frac{W_{\tau}}{P_{\tau}} \equiv w_{\tau}=\mathcal{M}_{w, \tau} M R S_{\tau}
$$

The labor supply equation (6) shows that because we assume that the labor market is imperfectly competitive with each household specializing in the supply of a different type of labor, real wages are set at a (gross) markup $\mathcal{M}_{w, \tau} \equiv \frac{\epsilon_{w, \tau}}{\epsilon_{w, \tau}-1}$ over the marginal rate of substitution between labor and consumption: $M R S_{\tau} \equiv-\left[\frac{\partial U_{\tau}}{\partial N_{\tau}} / \frac{\partial U_{\tau}}{\partial C_{\tau}}\right]$. Similarly, because each firm specializes in the production of an imperfectly substitutable good, it is able to charge a (gross) price markup $\mathcal{M}_{p, \tau} \equiv \frac{\epsilon_{p, \tau}}{\epsilon_{p, \tau}-1}$ over marginal cost $M C_{\tau} \equiv W_{\tau} / A_{\tau}$, such that:

$$
P_{\tau}=\mathcal{M}_{p, \tau} M C_{\tau}
$$

Total markup is defined as $\mathcal{M}_{p, \tau} \mathcal{M}_{w, \tau}$. Combining equations (6) and (7) yields $\mathcal{M}_{p, \tau} \mathcal{M}_{w, \tau}=\frac{A_{\tau}}{M R S_{\tau}} .{ }^{13}$ Perfect competition in goods and labor markets can be thought of as the limiting case when $\mathcal{M}_{w}=\mathcal{M}_{p}=1$.

\section{B. Deriving the World Natural Real Interest Rate}

Using households' and firms' first order conditions, we derive an analytical expression for the real natural interest rate. To simplify the algebra, we assume the following separable utility function:

$$
U_{\tau}\left(C_{\tau}, N_{\tau}\right) \equiv f\left(C_{\tau}\right)-v\left(N_{\tau}\right)
$$

where we posit:

$$
f\left(C_{\tau}\right) \equiv \ln C_{\tau} \text { and } v\left(N_{\tau}\right) \equiv k N_{\tau} .
$$

Now substituting a one-period ahead version of eq. (5) into the Euler equation (4), taking into account the pricing and the labor supply equations and ignoring Jensen's inequality terms, we can solve for the equilibrium real interest rate $r_{\tau}$ :

$$
1+r_{\tau} \equiv \frac{1+R_{\tau}}{E_{t} P_{\tau+1} / P_{\tau}} \simeq \beta^{-1} E_{t}\left(\frac{A_{\tau+1}}{A_{\tau}} / \frac{\mathcal{M}_{w, \tau+1} \mathcal{M}_{p, \tau+1}}{\mathcal{M}_{w, \tau} \mathcal{M}_{p, \tau}}\right)
$$

\footnotetext{
${ }^{13}$ Given the specification of utility used in Section 2.2 , the (gross) total markup is $\mathcal{M}_{p, \tau} \mathcal{M}_{w, \tau}=A_{\tau} / k C_{\tau}$, which is the equation used to compute the estimate of total markup in Figure 4.
} 
Therefore, defining the gross rate of productivity growth $g_{\tau+1} \equiv \frac{A_{\tau+1}}{A_{\tau}}$ and the growth rate of (gross) total markups $\Phi_{\tau+1} \equiv \frac{\mathcal{M}_{w, \tau+1} \mathcal{M}_{p, \tau+1}}{\mathcal{M}_{w, \tau} \mathcal{M}_{p, \tau}}$, the natural real interest rate can be written as

$$
1+r_{\tau} \simeq \beta^{-1} E_{t}\left(\frac{g_{\tau+1}}{\Phi_{\tau+1}}\right)
$$

Unsurprisingly, equation (8) shows that the real interest rate $r_{t}$ depends negatively on the 'patience' parameter $\beta$ and positively on expected productivity growth. ${ }^{14}$ The new feature is that progress in the integration of goods and labor markets-meaning in our simple set-up the expectation of falling equilibrium markups (i.e. $E_{\tau} \Phi_{\tau+1}<1$ )—leads to higher real interest rates than under the standard assumption of constant equilibrium markups. ${ }^{15}$ In short, the faster the pace of expected integration, the smaller $E_{\tau} \Phi_{\tau+1}$, the higher the 'globalization premium' and the natural real interest rate.

\section{Effects of Globalization on the Natural INTERest Rate}

\section{A. Non-Linear Implications of Global Integration}

An increase in global market power, due to e.g., increased protectionism would lead to a gradual increase in markups (i.e. $E_{\tau} \Phi_{\tau+1}>1$ ). Given the absence of an upper bound on the level of markups, the theoretical implications are the same as for a secular decline in TFP. The natural interest rate would decline as would output growth. In contrast, the global integration of goods and labor markets (the decline in equilibrium markups) has important non-linear implications for the natural interest rate. Unlike total factor productivity $A_{\tau}$, which can in principle increase at a constant pace for ever, the total (gross) markup $\mathcal{M}_{w, \tau} \mathcal{M}_{p, \tau}$ is bounded at 1 , which corresponds to perfect competition on both goods and labor markets.

To illustrate the impact of declining markups, assume that total markups asymptotically approaches a constant long-term level $\mathcal{M}_{w} \mathcal{M}_{p}=\overline{\mathcal{M}}$ according to the simple 1-parameter law of motion:

$$
\mathcal{M}_{\text {total }, \tau+1}-\overline{\mathcal{M}}=c\left(\mathcal{M}_{\text {total }, \tau}-\overline{\mathcal{M}}\right)
$$

where for notational convenience we have defined $\mathcal{M}_{\text {total }} \equiv \mathcal{M}_{w} \mathcal{M}_{p}$. Furthermore, $0<c<1$, $\mathcal{M}_{\text {total, } \tau} \geq \overline{\mathcal{M}}$. ${ }^{16}$ Taking expectations, equation (9) can be rewritten as:

$$
E_{t} \mathcal{M}_{\text {total }, \tau+1}=c \mathcal{M}_{\text {total }, \tau}+(1-c) \overline{\mathcal{M}}
$$

\footnotetext{
14 Note that the natural interest rate does not depend on population growth in an infinite horizon representative agent model. See Carvalho et al. (2016) for a theoretical derivation of the role of demographics on the natural interest rate in a life-cycle framework.

15 Laubach and Williams (2003) estimate a linear version of equation (8). Their specification includes a latent variable that captures movements in the natural rate of interest that are not associated with productivity growth but possibly, as the authors suggest, with changes in households' rate of time preference or fiscal policy. Our specification implies that this latent variable may also reflect changes in equilibrium markups dynamics.

${ }^{16}$ Again, none of our theoretical findings is affected by our assumption on the particular dynamic process for the markups. Any process that imply that the goods and labor gross markups converge towards their bounded longterm equilibrium as globalization proceeds would lead to the same conclusions.
} 
or equivalently:

$$
E_{t} \Phi_{\tau+1}=c+(1-c) \frac{\overline{\mathcal{M}}}{\mathcal{M}_{\text {total }, \tau}}
$$

for $\Phi_{\tau+1}=\frac{\mathcal{M}_{\text {total }, \tau+1}}{\mathcal{M}_{\text {total, } \tau}}$. Plugging equation (10) back into equation (8) yields:

$$
1+r_{\tau}=\beta^{-1} E_{t}\left(\frac{g_{\tau+1}}{\Phi_{\tau+1}}\right) \simeq \beta^{-1} E_{t} g_{\tau+1}\left(c+(1-c) \frac{\overline{\mathcal{M}}}{\mathcal{M}_{\text {total }, \tau}}\right)^{-1}
$$

Taking logs, equation (11) can be approximately rewritten as:

$$
r_{\tau} \simeq \rho+\delta_{\tau}+G P_{\tau}
$$

for $\rho=\ln \beta^{-1}$ and $\delta_{\tau}=\ln E_{t} g_{\tau+1}$. Compared to the standard neo-classical model, the new term is:

$$
G P_{\tau}=-\ln \left(c+(1-c) \frac{\overline{\mathcal{M}}}{\mathcal{M}_{\text {total }, \tau}}\right)
$$

that we referred to above as the 'globalization premium.'

Thus, the level of the natural interest rate depends on the parameter $c$ and the ratio between the current level of total markup $\mathcal{M}_{\text {total, } \tau}$ and its equilibrium value $\overline{\mathcal{M}}$. The faster globalization proceeds (the smaller is $c$ ), or the less competitive is the world economy compared to $\overline{\mathcal{M}}$ (the smaller is $\overline{\mathcal{M}} / \mathcal{M}_{\text {total, } \tau}$ ), the higher is the natural interest rate.

Equations (13) and (12) highlight the non-linear process. Over time, the globalization premium $G P_{\tau}$ tends to 0 as $\mathcal{M}_{\text {total, } \tau}$ converges to $\overline{\mathcal{M}}$, and the real natural interest rate becomes a function of the expected growth rate of productivity $\delta_{\tau}$ and the patience parameter $\rho$ only. This is an important and general result, which does not depend on the precise form of the dynamical process governing markups.

Equation (13) helps illustrate the interplay between globalization and real interest rates dynamics, as shown in Figure 1 and 4. From 1960 to 1970, globalization had not started in earnest yet, which can be interpreted as a parameter $c$ very close to 1 , implying a very small globalization premium. After 1970 and until the mid-1980s, the parameter $c$ dropped below 1 as the globalization process picked up pace, which combined with a small initial ratio $\overline{\mathcal{M}} / \mathcal{M}_{\text {total, } \tau}$ contributed to lift natural real interest rates, in line with the surge in the globalization premium. From mid-1980s onwards the parameter $c$ remained below 1 while the ratio $\overline{\mathcal{M}} / \mathcal{M}_{\text {total, } \tau}$ started to rise gradually, inducing a gradual erosion in the globalization premium and a decline in the natural real interest rates.

Note that equation (11) also makes clear that if the secular decline in the real interest rate had to be attributed to lower TFP growth or an increase in market power, global growth would have simultaneously declined, a development at odds with the data between 1990 and 2007 (see Figure 2). 


\section{B. How Large is the "Globalization Premium"?}

To get a better feel for the magnitudes implied by the analysis, the parameter $c$ is recast into a more intuitive measure of the pace of markups' decline. We define the half-life $h$ as the number of periods needed to halve the distance between initial markups and their long-term value (i.e. $\mathcal{M}_{\text {total }, \tau}-\overline{\mathcal{M}}$ ) or formally $c \equiv 2^{-\frac{1}{h}}$.

Figure 5 depicts the contour plot of equation (13), which summarizes the effect on the globalization premium of various combinations of half-life $h$ (expressed in years on the horizontal axis) and values for $\mathcal{M}_{\text {total, } \tau}$ (on the vertical axis) with $\overline{\mathcal{M}}$ assumed equal to 1 (perfect competition). Figure 5 shows that given plausible ranges for markups and their half-lives, the globalization premium can be sizable.

To our knowledge, there is very limited empirical evidence on the evolution of goods and labor markets markups over time. However, we can still analyze the implication of various assumptions for the natural interest rate according to equation (11). For example, setting an overall (net) markup level of 60 percent (i.e. $\mathcal{M}_{\text {total, } \tau}=1.6$ ), which corresponds approximately to the average of total markups (i.e., wage and price markups) in the US and the euro area given by Bayoumi et al. $\left(2004\right.$, Table 4, p. 45), ${ }^{17}$ and assuming that it takes about 25 years to halve them $\left(\mathcal{M}_{\text {total }, \tau+25}=1.3\right)$, the 'globalization premium' would account for about one percentage point of the natural real interest rate. Figures 6 and 7 depict the dynamics of markups and of the globalization premium in two cases. The first corresponds to a markups' half-life of 25 years (black line) and the other to a shorter half-life of 15 years (grey line). Both processes start with an initial (gross) markup of 1.6. A faster pace of globalization (shorter half-life) leads to a larger globalization premium (1.7 pp instead of $1.0 \mathrm{pp}$, see Figure 7 ) and a higher interest rate at $t=0$. Figure 7 shows that faster globalization would imply a larger premium for a considerable period, until the two trajectories approach each other as the positive effect of faster globalization is gradually offset by the negative effect of lower markup levels.

\section{EMPIRICAL EVIDENCE}

In this section we want to gain some empirical insight into the impact of globalization on the natural interest rate. We rely on a simple empirical specification derived from the above Euler equation and estimate the long-term relationship between real interest rates, change in market power and productivity growth. In Section 5 we will analyze the same question from the viewpoint of an open economy, structural, dynamic general equilibrium framework with capital accumulation, nominal, real and financial frictions.

\section{A. The Specification}

Previous sections have shown that the level of natural real interest rate is theoretically driven by the rate of time preference, expected productivity growth and the expected pace of globalization (i.e. change in markups). The relation is typically cast in terms of the short-term interest rate, but the expectation hypothesis implies that a similar relation should be found for the long-term

\footnotetext{
17 The estimates from Bayoumi et al (2004) are close to those given by Abraham et al (2009) for the Belgian manufacturing sector.
} 
interest rate as well. Assuming that the natural real interest is the driver of the low frequency movement of the observed real interest rate, we also estimate an equation for long-term interest rates. Long-term interest rates are in principle more amenable to the empirical analysis of market forces than short-term ones that may be dominated by central banks' actions.

Assuming no risk/liquidity premium, ${ }^{18}$ long-term ( $T$-period) real interest rate $1+r_{T, t}$ is:

$$
1+r_{T, t}=E_{t}\left\{\prod_{\tau=0}^{T}\left(1+r_{t+\tau}\right)\right\} / T,
$$

and from equation (12):

$$
r_{T, t} \simeq \rho+\frac{1}{T} E_{t} \sum_{\tau=0}^{T} \delta_{t+\tau}+\frac{1}{T} E_{t} \sum_{\tau=0}^{T} G P_{t+\tau} .
$$

The last term $G P_{t+\tau}$ depends on $\mathcal{M}_{\text {total }, t+\tau}$ through:

$$
G P_{t+\tau}=-\ln \left(c+(1-c) \frac{\overline{\mathcal{M}}}{\mathcal{M}_{\text {total }, t+\tau}}\right)
$$

Equation (9) can be iterated forward to give:

$$
\mathcal{M}_{\text {total }, t+\tau}=c^{\tau} \mathcal{M} \text { total }, t+(1-c) \overline{\mathcal{M}} \sum_{i=0}^{\tau-1} c^{i} .
$$

$G P_{t+\tau}$ is therefore a complicated function of the current level of markups $\mathcal{M}_{\text {total,t }}$ as well as the parameter $c$ and the long-term markup level $\overline{\mathcal{M}}$. We can write this function as $f_{\tau}\left(\mathcal{M}_{\text {total,t }}\right)$ and plug it in the equation for $r_{T, t}$ :

$$
r_{T, t} \simeq \rho+\frac{1}{T} E_{t} \sum_{\tau=0}^{T} \delta_{t+\tau}+\frac{1}{T} \sum_{\tau=0}^{T} f_{\tau}\left(\mathcal{M}_{\text {total }, t}\right),
$$

or

$$
r_{T, t} \simeq \rho+\Omega_{T, t}+\mathrm{F}_{T, t}
$$

where we see that the low frequency component of the long-term real interest rate is determined by the rate of time preference parameter $\rho$, a function of future expected annual productivity growth for the corresponding maturity $\Omega_{T, t}=\frac{1}{T} E_{t} \sum_{\tau=1}^{T+1} \log \left(g_{t+\tau}\right)$ and a function of the level of markups at time $t, \mathrm{~F}_{T, t}=\frac{1}{T} \sum_{\tau=0}^{T} f_{\tau}\left(\mathcal{M}_{\text {total }, t}\right)$.

This specification suggests a simple linear model where the long-term real interest rate is driven by $\mathrm{F}_{T, t}$ and $\Omega_{T, t}$ :

$$
\begin{gathered}
r_{T, t}=\hat{\mu}+\hat{\alpha} \times \mathrm{F}_{T, t}+\hat{\beta} \times \Omega_{T, t}+\varepsilon_{t} . \\
\varepsilon_{t}=\theta_{1} \varepsilon_{t-1}+\ldots+\theta_{n} \varepsilon_{t-n}+u_{t}+\gamma_{1} u_{t-1}+\ldots+\gamma_{p} u_{t-p}
\end{gathered}
$$

\footnotetext{
${ }^{18}$ Empirically, it does not matter as the value of the premium will be split between the constant and the residual.
} 
and where an $\operatorname{ARMA}(n, p)$ structure for the error term is allowed to account for deviations from the natural level of interest rates and potential additional drivers (such as e.g., demographics). It also ensures unbiased standard deviations estimates and valid T-stats.

A priori, $\hat{\alpha}$ and $\hat{\beta}$ are expected to be positive. The constant $\hat{\mu}$ is driven by factors such as the rate of time preference, the long-term markup $(\overline{\mathcal{M}})$ and the pace of globalization $c$ (all assumed constant here)

\section{B. Data Regression Results}

At the global level, data availability is an important issue in implementing (14). We base our analysis on a sample of annual data spanning the period between 1985 and 2016. Import penetration of goods and services is a common measure of the intensity of exposure to international competition, and is seen as a proxy for market power. ${ }^{19}$ We approximate $\mathcal{M}_{\text {total,t }}$ by the inverse of a global measure of import penetration provided by the World Bank. ${ }^{20}$ The global real interest rates, both short (1 year) and long-term (10 years), are computed by the IMF (IMF 2014) and the global multifactor productivity growth is based on a weighted average (PPP weights 2013) of annual TFP growth in the G20 countries (OECD Statistics).

A crude time series analysis (Box-Jenkins) of global TFP growth suggests a white noise process with a positive and significant constant, which implies that the level of productivity follows a random-walk with drift. In this case, the best forecasting model for TFP growth would be a constant and the regression (14) would simplify to:

$$
\begin{gathered}
R_{T, t}=\hat{\kappa}+\hat{\alpha} \times \mathrm{F}_{t}+\varepsilon_{t} \\
\varepsilon_{t}=\theta_{1} \varepsilon_{t-1}+\ldots+\theta_{n} \varepsilon_{t-n}+u_{t}+\gamma_{1} u_{t-1}+\ldots+\gamma_{p} u_{t-p}
\end{gathered}
$$

However, as we want to remain agnostic regarding the agents' expectation formation process, we estimate two polar cases, for $T=1$ (short-term interest rate, ST) and $T=10$ (long-term interest rate, LT). In the first case, we assume that future growth rates of productivity can be perfectly predicted (perfect foresight PF), and we replace the expected values of $g_{t+\tau}$ by their realized values in equation (14). In the second case we assume that expectations are naive and backward-looking (backward-looking $\mathrm{BL}$, where the average rate of productivity growth in the last three years is expected to continue in the future). ${ }^{21}$

\footnotetext{
${ }^{19}$ See Measuring Globalisation: OECD Economic Globalisation Indicators 2010. Very similar results were obtained by using the crude estimate of total markups show on Figure 4.

${ }^{20}$ As stated in the previous section, there exist to our knowledge no time series estimates of price and wage markups in world's main regions. As explained in footnote 11 and illustrated on Figure 4, we computed estimates for the OECD countries aggregate using OECD and Penn Table's data on productivity, labor compensation and consumption (estimates available from the authors). This (very crude) measure of total markups displays downward trend, which closely mirrors the (inverse) of the rise in world import penetration. The decline in the first part of the sample appears to come from diminishing price markups, while from the 90 s onward, it is driven by dwindling wage markups (not shown).

${ }^{21}$ We chose three years to avoid too large a loss of information at the beginning of the sample.
} 
Table 1 below confirms the preliminary TFP time series analysis and tends to favor the parsimonious specification (15). While the impact of TFP growth is not significant, globalizationproxied by the degree of import penetration-seems to be an important explanatory variable of the equilibrium value of real interest rates. The analysis of residuals shows that the relation is not spurious: the three variables are cointegrated and the Durbin-Watson statistic (close to 2) indicates that the T-stats are unbiased. The coefficients are stable and the relation fairly tight with a high adjusted R-Square. ${ }^{22}$ The simple model is not able to assert whether expectations are backward or forward-looking as both specifications are supported.

Table 1. OLS Estimates of Fundamental Drivers of Real Interest Rates, 1985-2016

\begin{tabular}{|c|c|c|c|c|c|c|c|}
\hline & & $\mathrm{mu}$ & alpha & beta & gamma1 & $\begin{array}{l}\text { R-squared } \\
\text { (adjusted) }\end{array}$ & DW \\
\hline \multirow{3}{*}{ PF } & ST & -27.32 & 38.18 & 0.00 & 0.59 & 0.83 & 1.81 \\
\hline & & $(-5.29)$ & (4.91) & 0.00 & (3.68) & & \\
\hline & LT & $\begin{array}{l}-25.46 \\
(-8.23) \\
\end{array}$ & $\begin{array}{l}37.70 \\
(8.06) \\
\end{array}$ & $\begin{array}{l}-0.66 \\
(-0.51)\end{array}$ & $\begin{array}{l}-- \\
--\end{array}$ & 0.84 & 2.14 \\
\hline \multirow{2}{*}{$B L$} & ST & $\begin{array}{l}-22.06 \\
(-5.32)\end{array}$ & $\begin{array}{l}29.35 \\
(5.59)\end{array}$ & $\begin{array}{c}2.61 \\
(3.91)\end{array}$ & $\begin{array}{c}0.93 \\
(8.66)\end{array}$ & 0.86 & 2.15 \\
\hline & LT & $\begin{array}{l}-21.70 \\
(-7.44)\end{array}$ & $\begin{array}{l}31.88 \\
(7.62)\end{array}$ & $\begin{array}{c}0.54 \\
(0.77)\end{array}$ & $\begin{array}{l}-- \\
--\end{array}$ & 0.82 & 2.36 \\
\hline
\end{tabular}

T-stat in parenthesis

While the results are consistent with our main thesis, they should be taken with a grain of salt since our short sample (31 annual observations) does not allow very precise estimates. ${ }^{23}$ The next section will push the analysis one step further and explore the implications of globalization for savings, inflation, growth and interest rates in the context of a large scale, 3-regions microfounded model calibrated for the US, the euro area and the rest of the world.

\section{INSIGHTS fROM A LARGe MOdel OF the Global ECONOMY}

In previous sections we kept the framework as simple as possible to highlight the main mechanisms. However, the non-linearity associated with the global integration of goods and labor markets also has important implications for investment, consumption, inflation, global savings and international wealth transfer. This section re-examines the global effect of declining markups in the context of a much richer framework. We use the Global Integrated Monetary and Fiscal Model (GIMF)—a multi-country micro-founded general equilibrium model developed and used extensively at the IMF and other institutions for policy analysis (Kumhof et al. 2010) - to show that our conclusions regarding the effect of globalization on real interest rates hold up when capital accumulation, nominal and real frictions as well as open economy dimensions are taken into account.

\footnotetext{
${ }^{22}$ According to an Engle-Granger cointegration test over the sample 1985-2016, p-values for the null hypothesis of no cointegration (with trend) of the tau- and z-statistic are 0.0051 , resp. 0.0000 . The Phillips-Ouliaris test yielding $p$-values of 0.0011 and 0.0262 respectively.

${ }^{23}$ Note that a VECM estimation of the postulated long-term relationship yields very similar results and shows that the globalization proxy dominates TFP growth (insignificant) as the driver of real interest rates. The analysis is available upon request.
} 


\section{A. GIMF in a Nutshell}

The IMF's Global Integrated Monetary and Fiscal model (GIMF) is a large, multi-region microfounded dynamic general equilibrium model. In GIMF, both households and firms are forwardlooking and base their decisions on intertemporal maximization of utility and profit. Firms produce tradable and non-tradable intermediate goods which are combined with imported intermediate goods to product final goods for consumption and investment, both private (which are also internationally traded) and public. Firms operate in monopolistically competitive markets, setting prices by adding a markup over marginal costs. Manufacturers of intermediate goods buy labor from monopolistically competitive unions which set wages at a markup over workers' marginal rate of substitution between leisure and consumption. The model features full intertemporal stock-flow consistency and various nominal and real frictions such as e.g., sticky prices and wages, real adjustment costs, financial frictions.

Importantly, GIMF is based on the Blanchard-Weil-Yaari overlapping generations (OLG) framework which leads to a significant departure from Ricardian equivalence. This has important implications for the impact of structural changes on global savings and the equilibrium longterm interest rate. The non-Ricardian nature of the OLG households is enhanced by the presence of liquidity-constrained (LIQ) households. They consume their labor income each and every period, as well as any transfers they receive from the government. ${ }^{24}$

The model's fiscal rule maintains a stable long-run debt-to-GDP target and fiscal policy is conducted using seven instruments: government spending, government investment (infrastructure spending), general and targeted lump-sum transfers, a consumption tax (VAT), a corporate income tax, and a labor income tax. In each region, monetary policy follows a standard CPI-inflation-forecast-based interest rate reaction function. Importantly in our context, GIMF accommodates shifts in the model's steady-state as structural parameters, such as markups, are changed.

\section{B. Calibration}

In this paper, we use a 3-region version of the model calibrated for the US, the euro area and remaining countries. We set starting (net) markups in 1980 to 40 percent in the goods sectors and to 20 percent in the labor market, such that they add up to 60 percent, the calibration chosen in section 3.1. We then simulate a gradual decrease in markups in all the sectors facing foreign competition. In line with the analysis in Section 3, markups decline at a pace corresponding to a half-life of 25 years. ${ }^{25}$ The same assumption applies to the wage markups set by labor unions in the model. Regarding markups and their dynamics, all three regions (U.S., Euro area and remaining countries) are treated symmetrically for simplicity.

\footnotetext{
${ }^{24}$ LIQ households are typically assumed to represent 25 percent of total households in advanced economies and 50 percent in emerging markets.

25 We also assume a more gradual decline in markups in the non-traded sector (half-life of 50 years), to allow for a broad impact of globalization on the economy. This is to reflect the fact that globalization may force lower markups in sectors that are increasingly subject to international competition even if no trade effectively takes place or if it is not well measured (e.g., for services).
} 


\section{Simulation's Results}

Figure 8 depicts the effect on the short- and long-term real interest rate in the US. As the model is specified on a yearly basis, the short-term rate is the $1 \mathrm{Y}$ bond yield, and the long-term rate is the $10 \mathrm{Y}$ bond yield. Interest rates in the two other regions follow very similar patterns (not shown) due to (assumed) similar markup dynamics.

Interest rates rise during the first decade, reflecting the emergence of the 'globalization premium' and peak in the second half of the 1980s around $0.9 \mathrm{pp}$ above their initial steady-state, which is close to the results of the simulations performed with the simple model of Section 3 (Figure 7). After having peaked, real interest rates decline as agents adjust to the gradual decrease in markups, as predicted by the model in Section 3. However, in contrast to the results in Section 3, the response of short-term interest rates is hump-shaped, reflecting the various frictions present in GIMF (which delay the adjustment of consumption and investment demand to expected higher long-term output) and the staggered response of policy rates to the output gap and inflation. Long-term interest rates respond more quickly due to the forward-looking nature of agents in the model. Note that the output and inflation responses (Figure 9) are also conform to intuition. Lower markups are expected to lead to higher output and lower inflation, which is in line with global trends in the last three decades (Figure 2 and 3).

\section{SUMmARY AND CONCLUSION}

We argue that globalization and the associated change in market power in the goods and labor markets can be a significant driver of global real interest rates. Our analysis and simulations find a potentially significant 'globalization premium'-a measure of the positive contribution of globalization to the level of the natural interest rate which emerged in the 1980s, a period of intensifying economic integration in Europe, East-Asia and North America and which may have been as high as one percentage point per annum. Simple regression analysis suggests that when globalization is taken into account, TFP growth does not play a significant role in explaining the secular decline in interest rates. At the same time, the simulation performed with a large multiregion model of section 5 suggests that the 1980s 'globalization premium' has almost vanished (see Figure 8) as gains in competition have slowed, thus providing a partial explanation of the persistent downward trend in real rates from the mid-1980s.

Our analysis also points to important implications for the future path of interest rates. Absent significant changes in expectations regarding the underlying pace of global integration, we can conjecture that long-term real interest rates will not revert to the levels reached in the last four decades. Moreover, a retrenchment from globalization, or more generally a rise in market power, could push growth and natural rates further down. 


\section{Appendix: Figures}
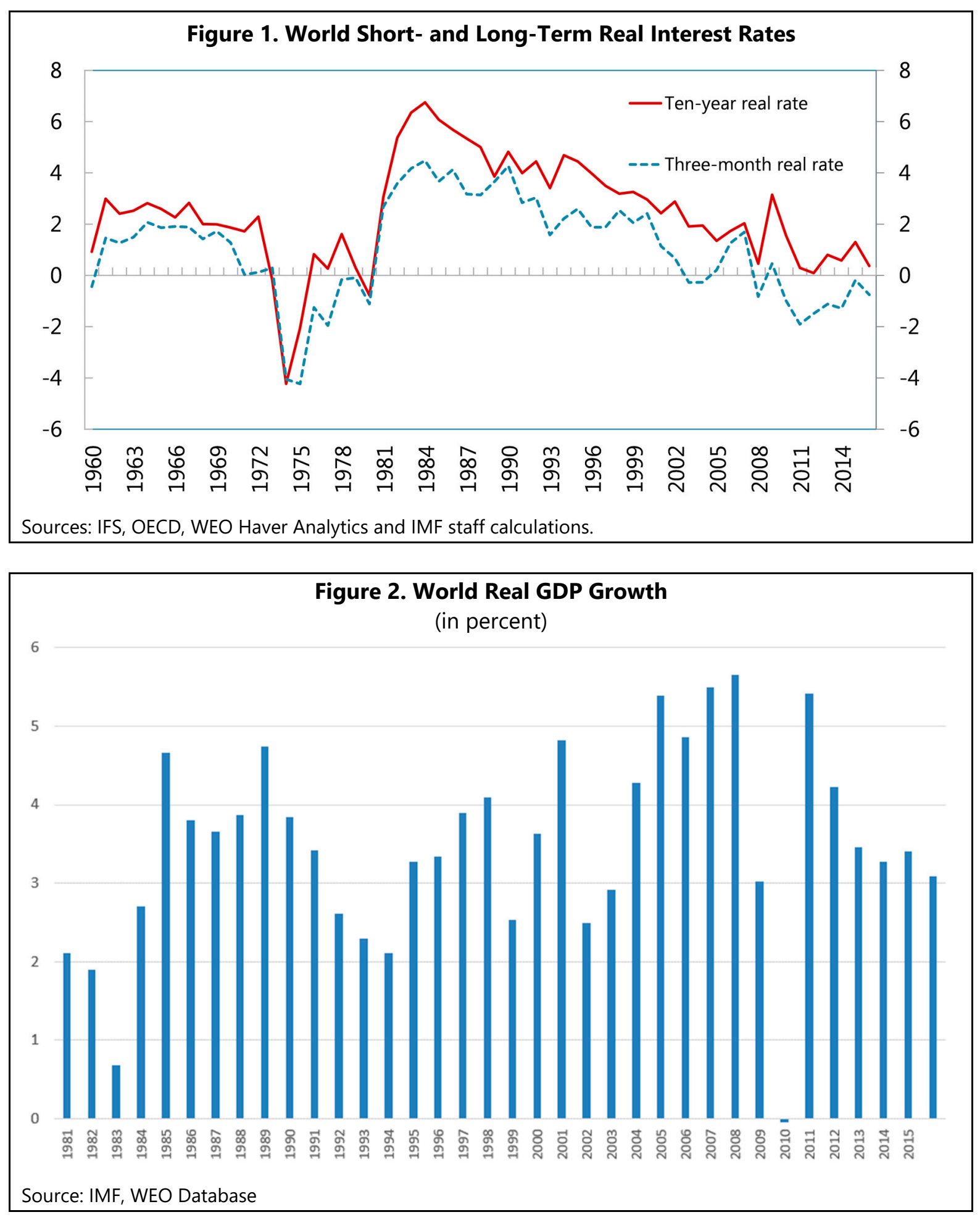


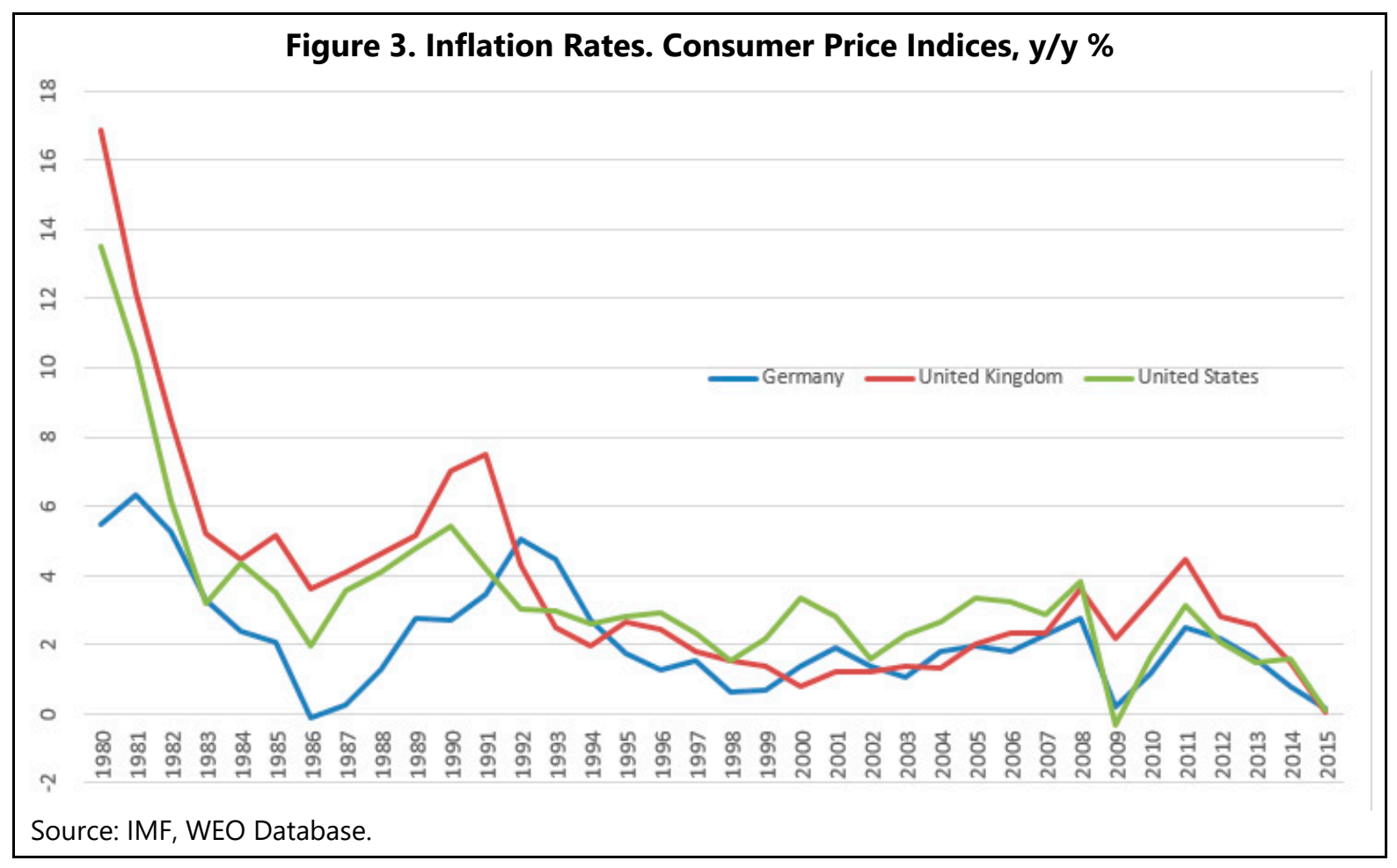

Figure 4. Total Gross Markup and (inverted) World Import Penetration (World GDP/World Total Imports in USD). Total Gross Markup equals the sum of Price Markup and Wage Markup. Index: $1970=1$

1.05

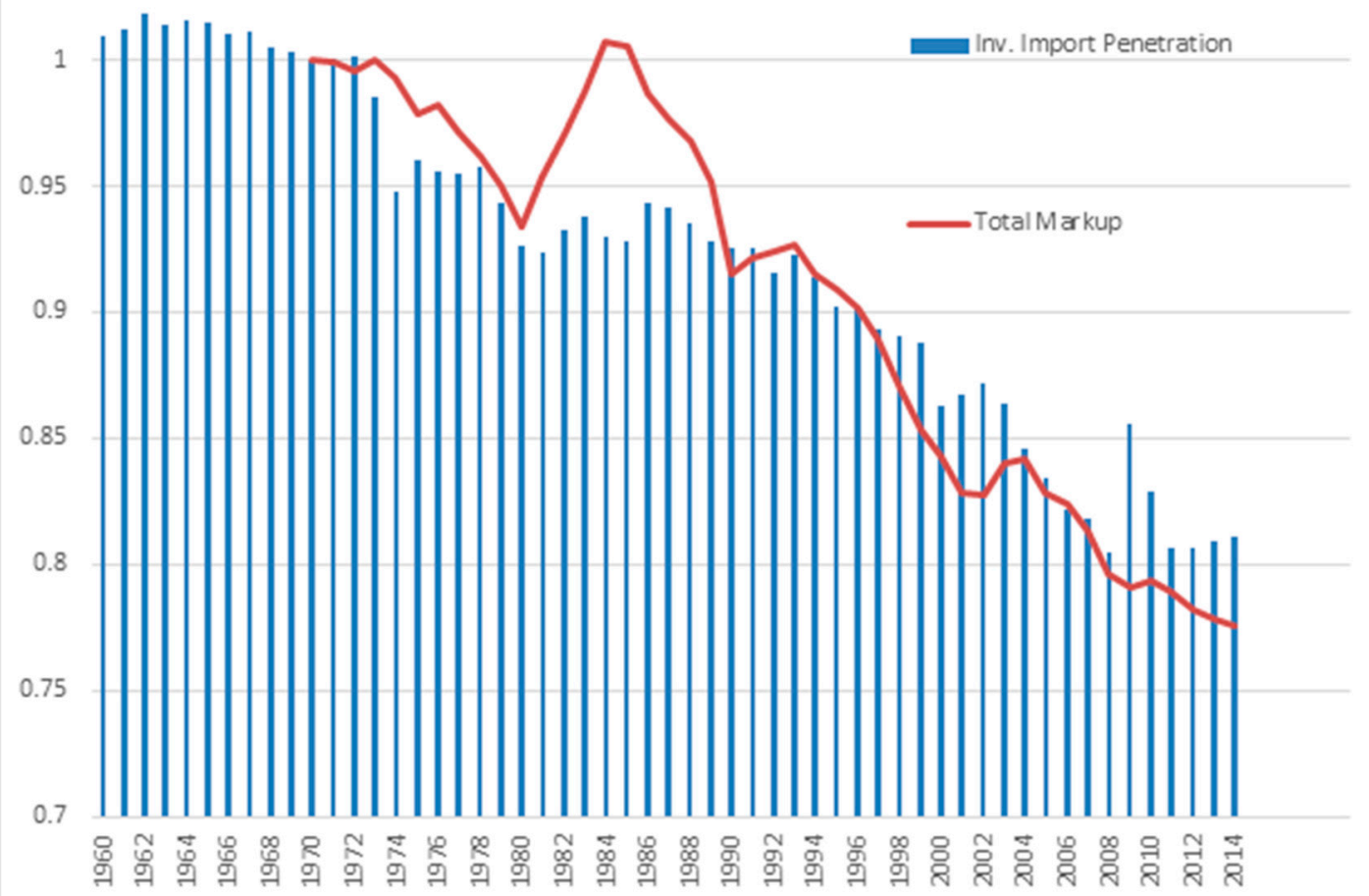

Sources: World Bank, Penn World Table, OECD.

Note: The composition of the total growth markup is further explained in footnotes 11 and 16 . 
Figure 5. Globalization Premium as a Function of the Markups Pace of Decline and their

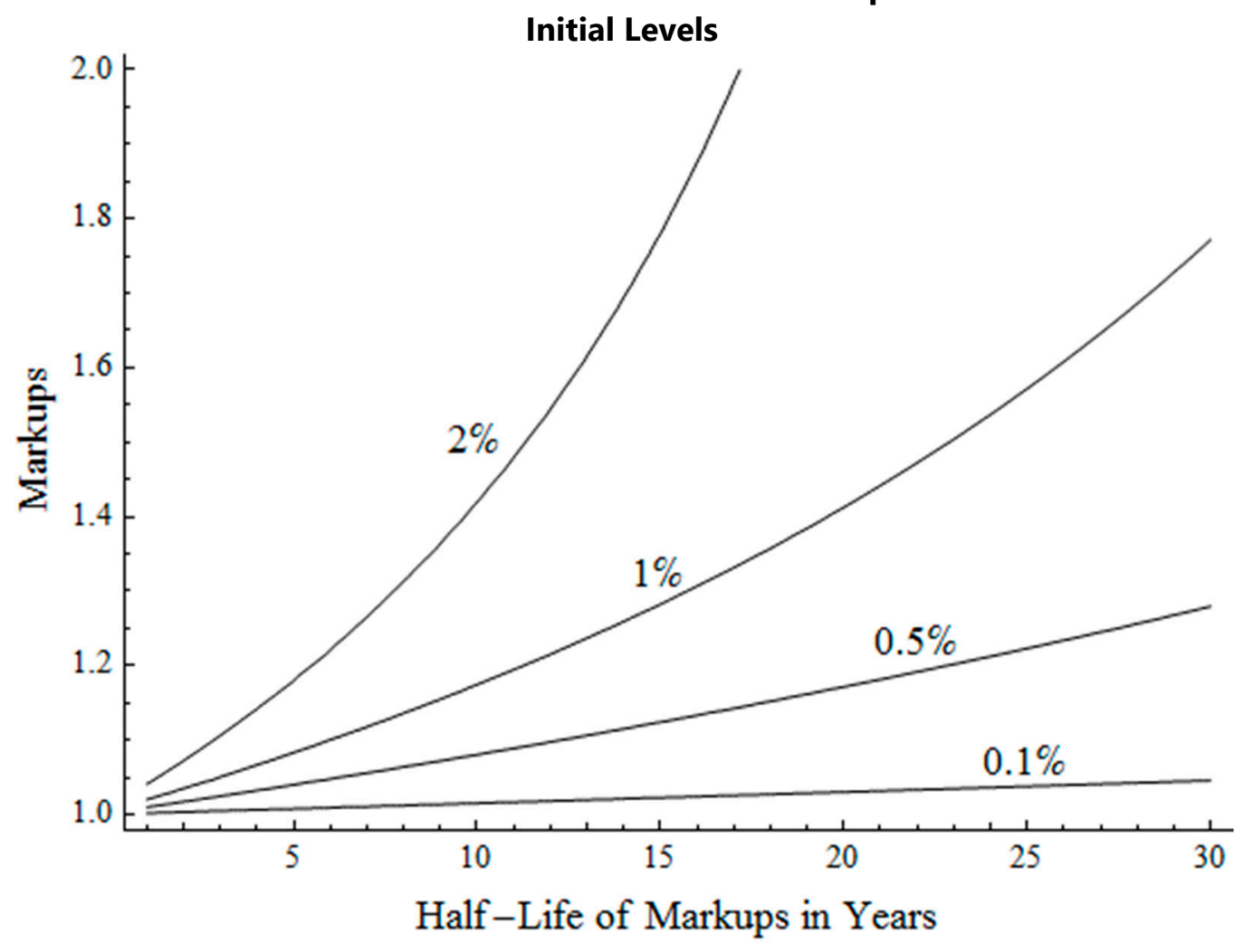

Figure 6. Markups with Different Pace of Decline

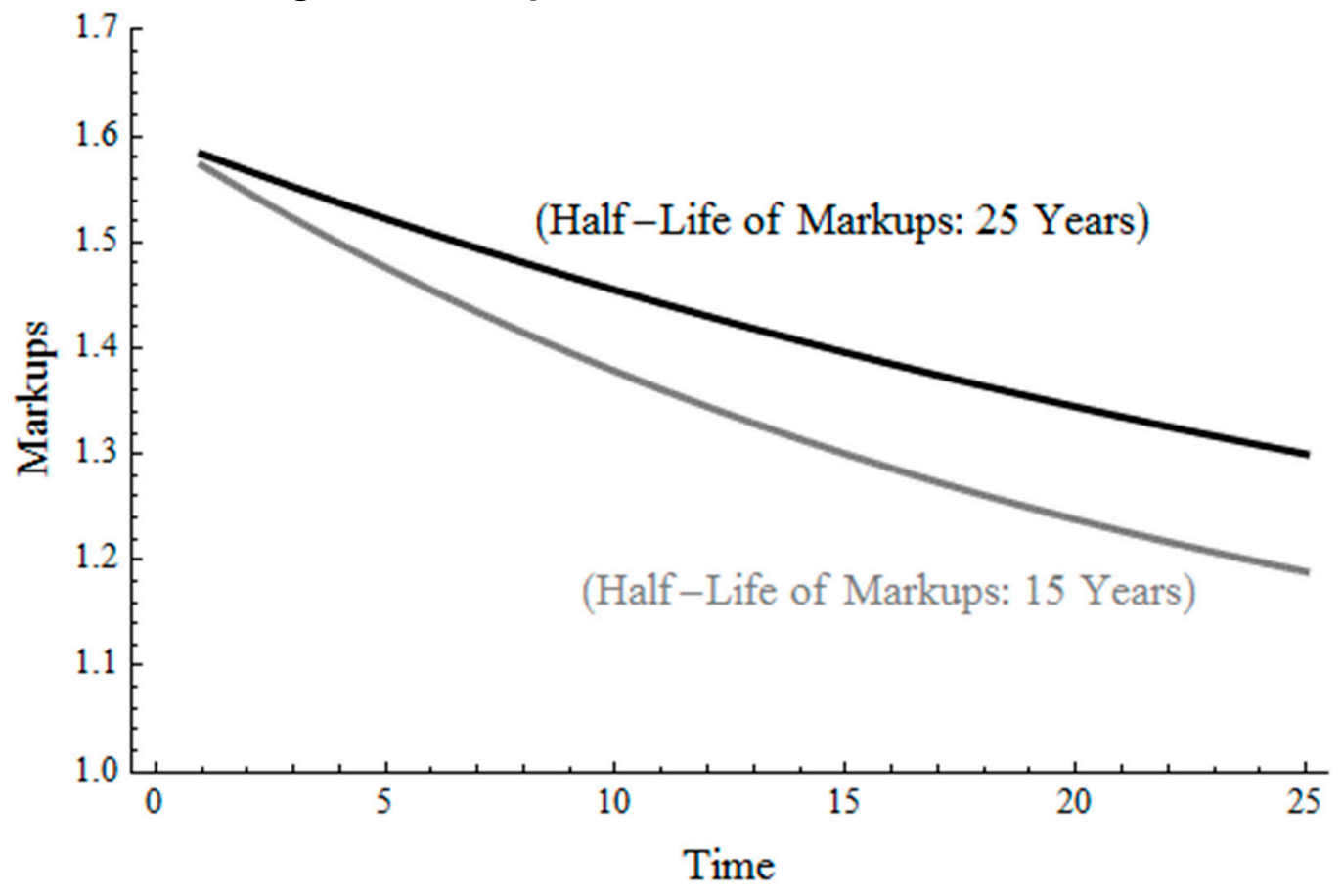




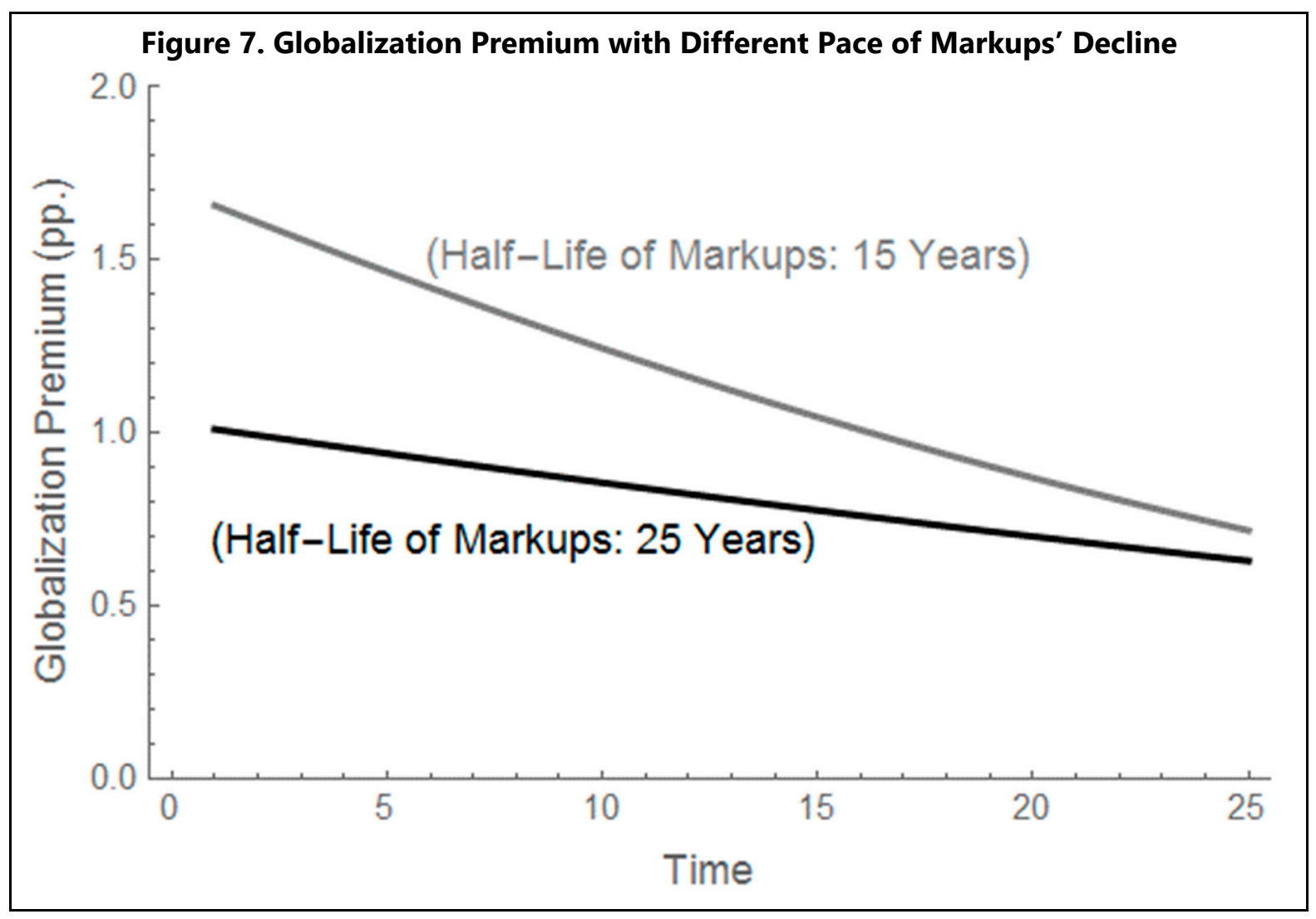

Figure 8. GIMF: Simulated 1Y- and 10Y Real Interest Rates (US). Differences in pp from Initial Steady-State. Global Markups Decline starts in 1980 (Half-life 25 years)

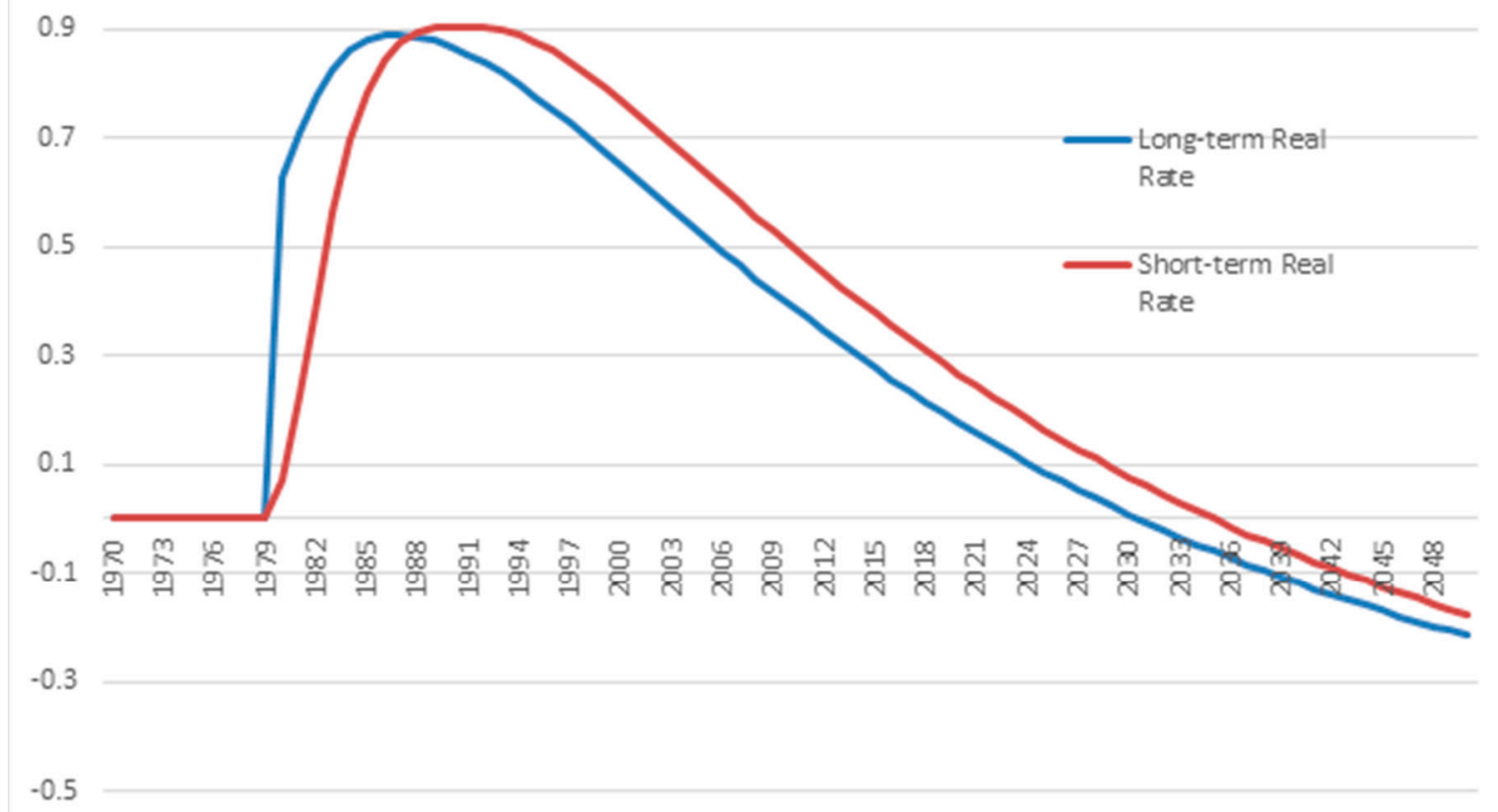


Figure 9. GIMF: Simulated GDP Growth and CPI Inflation (US). Differences in pp from Initial Steady-State. Global Markups Decline starts in 1980 (Half-life 25 years)

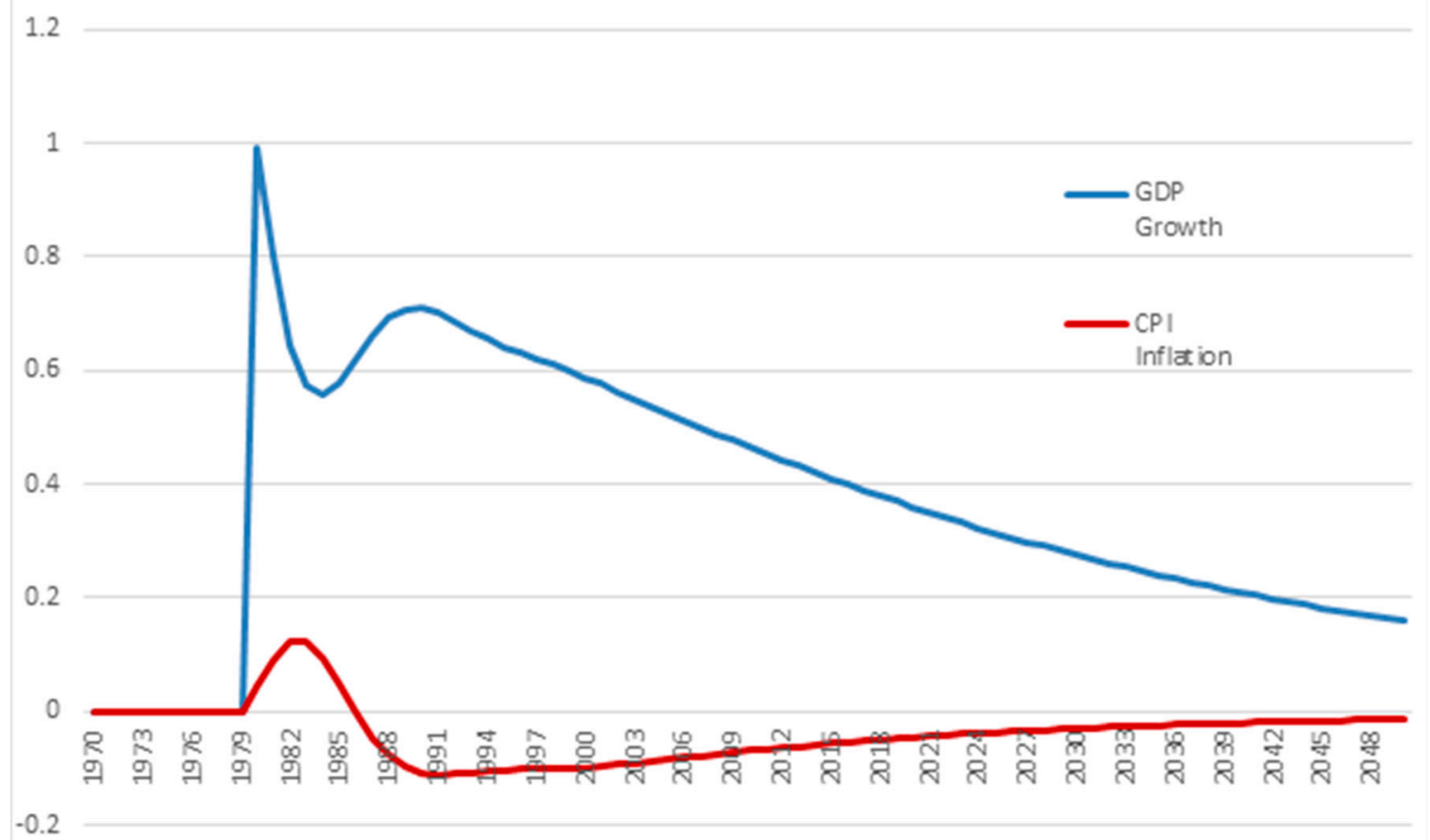




\section{References}

Abraham, Filip, Jozef Konings, and Stijn Varnomelingen "The effect of globalization on union bargaining and price-cost margins of firms," Review of World Economics 145 (1), 2009, pp.13-36.

Badinger, Harald, "Has the EU's Single Market Programme Fostered Competition? Testing for a Decrease in Mark-up Rations in EU Industries," Oxford Bulletin of Economics and Statistics, 60(4), 2007, 497-512.

Bayoumi, Tamin, Douglas Laxton, and Paolo Pesenti, "Benefits and spillovers of greater competition in Europe," ECB Working Paper Series, No. 341, April 2004.

Bernanke, Ben, "The Global Saving Glut and the U.S. Current Account Deficit," Sandridge Lecture, Virginia Association of Economics, Richmond, Virginia, March 2005.

Boulhol, Hervé, Sabien Dobbelaere, and Sara Maioli, "Imports as Product and Labour Market Discipline," British Journal of Labour Relations 49(2), 2011, p.331-361.

Caballero, Ricardo J, Emmanuel Farhi, and Pierre-Olivier Gourinchas, "The Safe Assets Shortage Conundrum," Journal of Economic Perspectives 31(3), 2017, p. 29-46.

Carvahlo, Carlos, Andrea Ferrero, and Fernanda Nechio, "Demographic Transition and Low U.S. Interest Rates", Federal Reserve Bank Economic Letter 27, Federal Reserve Bank of San Francisco, September 25, 2017.

Chen, Natalie, Jean Imbs, and Andrew Scott, "The dynamics of trade and competition," Journal of International Economics 77, 2009, p. 50-62.

Cynamon, Barry Z. and Steven M. Fazzari, "Inequality, the Great Recession, and Slow Recovery", Institute for New Economic Thinking Working Paper Series, No. 9, October 2014.

De Blas, Beatriz, and Katheryn N. Russ, "Understanding Markups in the Open Economy," American Economic Journal: Macroeconomics 7(2), 2015, 157-180.

Del Negro, Marco, Domenico Giannone, Marc P. Giannoni, and Andrea Tambalotti, "Safety, Liquidity, and the Natural Rate of Interest," Brookings Papers on Economic Activity, Spring 2017, 235-294.

De Loecker, Jan, and Jan Eeckhout,"The Rise of Market Power and the Macroeconomic Implications," NBER Working Paper 23687, August 2017.

Deutsche Bundesbank, "Mark-ups on Firms in Selected European Countries", Monthly Report December 2017, Frankfurt am Main, 2017.

Diez, Federico J., Daniel Leigh, and Suchanan Tambunlertchai, "Global Market Power and its Macroeconomic Implications," IMF Working Paper 18/137, June 2018.

Dobbelaere, Sabien, "Joint Estimation of Price-Cost Margins and Union Bargaining Power for Belgian Manufacturing," IZA Discussion Paper 1466, January 2005. 
Edmond, Chris, Virgiliu Midrigan, and Daniel Yi Xu, "Competition, Markups, and the Gains from International Trade," American Economic Review 105(10), 2015, 3183-3221.

Eggertson, G., Mehrotra N. "A Model of Secular Stagnation," mimeo, Brown University, April 2014.

Feenstra, Robert C., Inklaar Robert, and Trimmer, Marcel P., "The Next Generation of the Penn World Table", American Economic Review, 105(10), 3150-3182, 2015.

Feenstra, Robert C., and David E. Weinstein, "Globalization, Markups, and US Welfare," Journal of Political Economy 125(4), 2017, 1040-1073.

Fischer, Stanley, "The Low Level of Global Real Interest Rates," Conference to Celebrate Arminio Fraga's 60 Years, Casa das Garcas, Rio de Janeiro, Brazil, July 2017.

Freund, Caroline, and Dario Sidhu,"Global Competition and the Rise of China," PIIE Working Paper 17-3, February 2017.

Gagnon, Etienne, Benjamin K. Johannsen, and David Lopez-Salido, Ünderstanding the New Normal: The Role of Demographics", Finance and Economics Discussion Series 080, Board of Governors of the Federal Reserve System, 2016.

Gali, Jordi, "Monetary Policy, Inflation and the Busines Cycle: An Introduction to the New Keynesian Framework," Princeton University Press, 2008.

Gourinchas, Pierre-Olivier, and Hélène Rey, "Global Real Rates: A Secular Approach," Mimeo, April 2017.

Gutierrez, German, and Thomas Philippon,"Declining Competition and Investment in the US," NBER Working Paper 23583, July 2017.

Hamilton, James D., Etahn S. Harris, Jan Hatzius, and Kenneth D. West, "The Equilibrium Real Funds Rate: Past, Present, and Future," Hutching Center at Brookings Working Paper 16, October 2015.

Harrison, Ann E., "Productivity, imperfect competition and trade reform: Theory and evidence," Journal of International Economics 36, 1994, 53-73.

Holston, Kathryn, Thomas Laubach, and John C. Williams, "Measuring the Natural Rate of Interest: International Trends and Determinants," Federal Reserve Bank of San Fransisco Working Paper 11, 2016.

International Monetary Fund, "Chapter 3: Perspectives on Global Real Interest Rates," World Economic Outlook April 2014, Washington D.C., 2014.

__ "Chapter 2: The Rise of Corporate Market Power and its Macroeconomics effects," World Economic Outlook April 2019, Washington D.C., 2019.

Krugman, Paul, "Increasing returns, monopolistic competition and international trade" Journal of International Economics 9(4), 1979, 469-479. 
Kumhof, Michael, Douglas Laxton, Dirk Muir, and Susanna Mursula,"The Global Integrated Monetary and Fiscal Model (GIMF) - Theoretical Structure", IMF Working Paper WP/10/34, 2010.

Laubach, Thomas, and John C. Williams "Measuring the Natural Rate of Interest," The Review of Economics and Statistics 85(4), 2003, 1063-1070.

Levinsohn, James, "Testing the imports-as-market-discipline hypothesis," Journal of International Economics 35, 1993, 1-22.

Lubik, Thomas A., and Christian Matthes, "Calculating the Natural Rate of Interest: A Comparison of Two Alternative Approaches," Economic Brief EB15-10, Federal Reserve Bank of Richmond, October 2015.

Marx, Magali, Benoît Mojon, and Francois R. Velde, "Why Have Interest Rates Fallen far Below the Return on Capital?," Banque de France Working Paper 630, May 2017.

Natal, Jean-Marc, and Nicolas J. Stoffels, "Globalization, markups and the natural rate of interest," Swiss National Bank Working Papers, No. 14, November 2007.

Obstfeld, Maurice and Linda L. Tesar, "Long-Term Interest Rates: A Survey," A Report by Council of Economic Advisers, Executive Office of the President of the United States, July 2015.

OECD, OECD Economic Outlook Database, November 2017, accessed on December $15^{\text {th }}$.

OECD, "Globalisation, jobs and wages," Policy Brief, June 2007.

Picketty, Thomas, and Emmanuel Saez, "Inequality in the long-run", Science 344(6186), 2014.

Rodrick, Dani, "Has globalization gone too far," Institute for International Economics, Washington D.C., 1997.

Sajedi, Rana, and Gregory Thwaites,"Why Are Real Interest Rates So Low? The Role Of Relative Prices Of Investment Goods," IMF Economic Review 64(4), International Monetary Fund, 2016.

Summers, L., U.S. Economic Prospects: Secular Stagnation, Hysteresis, and the Zero Lower Bound," Business Economics 49, 2014, 65-73.

Traina, James, "Is Aggregate Market Power Increasing? Production Trends Using Financial Statements", Stigler Center New Working Paper Series, No. 17, 2018.

Tybout, James R., "Plant- and Firm-Level Evidence on "New" Trade Theories," NBER Working Paper 8418, 2001.

Williams, John C., "Three Questions on R-star", Federal Reserve Bank Economic Letter 05, Federal Reserve Bank of San Francisco, February 21, 2017.

Yi, Kei-Mu, and Jing Zhang, "Real Interest Rates Over the Long Run. Decline and convergence since the 1980s," Federal Reserve Bank of Minneapolis Economic Policy Paper 16-10, September 2016. 